\title{
ANTIPROLIFERATIVE EFFECTS OF SELECTED CHEMOTHERAPEUTICS IN HUMAN OVARIAN CANCER CELL LINE A2780
}

\author{
Kateřina Caltová, Miroslav Červinka
}

Charles University in Prague, Faculty of Medicine in Hradec Králové, Czech Republic: Department of Medical Biology and Genetics

\begin{abstract}
Summary: The aim of our study was to determine the effect of selected cytostatics on a human ovarian cancer cell line A2780 as a model system for ovarian cancer treatment. This cell line is considered cisplatin-sensitive. Panel of tested cytostatics included cisplatin, paclitaxel, carboplatin, gemcitabine, topotecan and etoposide. These cytostatics have a different mechanism of action. To evaluate cytotoxic potential of the tested compounds, the methods measuring various toxicological endpoints were employed including morphological studies, MTT assay, dynamic monitoring of cell proliferation with xCELLigence, cell cycle analysis, caspase 3 activity and expression of proteins involved in cell cycle regulation and cell death. The A270 cell line showed different sensitivity towards the selected cytostatics, the highest cytotoxic effect was associated with paclitaxel and topotecan.
\end{abstract}

Key words: A2780; Cytostatics treatment; Chemosensitivity testing; Cisplatin; Topotecan

\section{Introduction}

Ovarian cancer is the fifth most common cancer in women and the leading cause of death from gynecologic malignities. Annualy about 1200 new cases of this malignancy are diagnosed in the Czech Republic and about 700 women die (8). Ovarian tumours are classified as chemosensitive tumours but not chemocurable tumours. Therapeutic treatment of ovarian cancer patients involves surgery with maximal cytoreduction, subsequent chemotherapy and exceptionally also radiotherapy (7). Administration of platinum derivative and paclitaxel in combination constitutes first line standard for patients with advanced epithelial ovarian cancer (30), yielding response in about $80 \%$ of patients (4).

In cases of recurrence the treatment is problematic because there is a lack of therapeutic standard. Retrospective studies of platinum-based second-line therapies have identified two subgroups of patients with recurrent ovarian cancer: those with platinum-sensitive disease (DFI $>6$ months) when platinum derivatives can be used again and those with platinum-resistant disease (disease free interval DFI $\leq 6$ months) when platinum derivatives are not used in second-line chemotherapy again $(20,29)$. In those cases second and further lines of chemotherapy include paclitaxel alone, topotecan, liposomal doxorubicin or gemcitabine (7).

Cytotoxic mechanism-oriented studies of clinicaly applied agents are often carried out on model systems in vitro to provide mechanistic feedback into the efficiency and usefullness of particular chemotherapeutic regimens. Here we used human epithelial ovarian cancer cell line
A2780, which is considered as cisplatin sensitive (according to the ECACC catalog, cell line code: 93112519). This cell line was employed as a model for further investigation of the inhibitory and proapoptotic activities of selected cytostatics.

\section{Matherials and methods}

\section{Cell line}

Human ovarian cancer cell line A2780 was obtained from European Collection of Animal Cell Cultures (ECACC, Porton Down, Wiltshire, England, Cat. No 93112519). Cells were grown as adherent cultures in medium RPMI $1640+2 \mathrm{mM}$ glutamine and 10\% fetal bovine serum at $37^{\circ} \mathrm{C}$ and $5 \% \mathrm{CO}_{2}$. They were passaged three times a week, trypsinized using $0.25 \%$ trypsin solution with EDTA at $37^{\circ} \mathrm{C}$ and $5 \% \mathrm{CO}_{2}$.

\section{Cytostatic treatment}

The concentration range of selected cytostatics (Tab. 1) was chosen according to the schedule employed in previous studies using clinical samples (5). Every cytostatic was tested in six concentrations. The highest concentrations $\left(\mathrm{c}_{1}\right)$ of tested cytostatics were as follow: cisplatin $\mathrm{CisPt}$ (EBEWE Pharma Ges.mbH. Nfg.KG, Austria) $100 \mu \mathrm{g} / \mathrm{ml}$, paclitaxel PTX (Pliva-Lachema a.s., Czech Republic) $50 \mu \mathrm{g} / \mathrm{ml}$, carboplatin CBDCA(EBEWE Pharma Ges.m.b.H. Nfg.KG, Austria) $100 \mu \mathrm{g} / \mathrm{ml}$, gemcitabine Gmc (Gemzar 
Tab. 1: Concentration ranges of tested cytostatics

\begin{tabular}{|c|c|c|c|c|c|c|}
\hline \multirow{2}{*}{ Concentration } & \multicolumn{6}{|c|}{ Cytostatics } \\
\cline { 2 - 7 } & CisPt & PTX & CBDCA & Gmc & Topo & Etop \\
\hline $\mathbf{c}_{1}(\mu \mathrm{g} / \mathrm{ml})$ & 100 & 50 & 100 & 300 & 50 & 50 \\
\hline $\mathbf{c}_{2}(\mu \mathrm{g} / \mathrm{ml})$ & 25 & 12.5 & 25 & 75 & 12.5 & 12.5 \\
\hline $\mathbf{c}_{3}(\mu \mathrm{g} / \mathrm{ml})$ & 6.25 & 3.13 & 6.25 & 18.75 & 3.13 & 3.13 \\
\hline $\mathbf{c}_{4}(\mu \mathrm{g} / \mathrm{ml})$ & $\mathbf{1 . 5 6}$ & $\mathbf{0 . 7 8}$ & $\mathbf{1 . 5 6}$ & $\mathbf{4 . 6 9}$ & $\mathbf{0 . 7 8}$ & $\mathbf{0 . 7 8}$ \\
\hline $\mathbf{c}_{5}(\mu \mathrm{g} / \mathrm{ml})$ & 0.39 & 0.20 & 0.39 & 1.17 & 0.20 & 0.20 \\
\hline $\mathbf{c}_{6}(\mu \mathrm{g} / \mathrm{ml})$ & 0.10 & 0.05 & 0.10 & 0.29 & 0.05 & 0.05 \\
\hline
\end{tabular}

200 mg, Eli Lilly, s.r.o., Czech Republic) $300 \mu \mathrm{g} / \mathrm{ml}$, topotecan Topo (Hycamtin $4 \mathrm{mg}$, GlaxoSmithKline, UK) $50 \mu \mathrm{g} / \mathrm{ml}$ and etoposide Etop (Teva Pharmaceuticals, s.r.o., Czech Republic) $50 \mu \mathrm{g} / \mathrm{ml}$. Lower concentrations were prepared using dilution factor of four. The middle inhibion concentration $c_{4}$ for each cytostatic was chosen for further studies. We use general term " $c_{4}$ " because its value is different for tested cytostatics. Concentrations $\mathrm{c}_{4}$ were nearest to the EC50 values for selected cytostatics obtained in testing of clinical samples.

\section{MTT assay}

Effect of tested cytostatics on metabolic activity of treated cells A2780 was evaluated by MTT assay and expressed as the EC50 values. MTT assay was carried out as described before (5).

\section{xCELLigence}

$\mathrm{xCELLigence} \mathrm{system} \mathrm{(Roche)} \mathrm{is} \mathrm{use} \mathrm{to} \mathrm{monitor} \mathrm{cyto-}$ toxicity, using electronic cell sensor array technology. xCELLigence E-plates were filled with $100 \mu \mathrm{R}$ RPMI medium/well and the background signal was determined. Next, $100 \mu \mathrm{l}$ of cell suspension was added in to each well $(25,000$ cells/well). Cells were allowed to adhere $(30 \mathrm{~min}$ at room temperature), E-plates were placed in the instrument and cell proliferation was monitored for $24 \mathrm{~h}$. Thereafter, tested cytostatics according to selected concentration ranges were added to cultivation media and cell index was recorded for next $72 \mathrm{~h}$. Together six concentrations of each cytostatic drug were tested (Tab. 1). EC50 values were determined for each cytostatic after $72 \mathrm{~h}$ of treatment.

\section{Morphological studies}

$10 \mathrm{ml}$ of A2780 cell suspension in a density of $2 \times 10^{5}$ cells $/ \mathrm{ml}$ were seeded into small tissue culture flasks and cultivated at $37^{\circ} \mathrm{C}$ and $5 \% \mathrm{CO}_{2}$ for 24 hours. Next, cultivation medium was removed and fresh medium with cytostatics at tested concentration ranges was added. At time intervals of $0 \mathrm{~h}, 24 \mathrm{~h}, 48 \mathrm{~h}$, and $72 \mathrm{~h}$, photographs of control and treated cells were obtained using Olympus IX70 microscope and JVC color video camera (Victor Company of Japan) at magnification of $400 \times$. Photographs were analysed by LUCIA (NIS Elements).

\section{Cell cycle analysis}

Control and treated cells were trypsinised and harvested to the centrifuge tubes. After the centrifugation cells were rinsed with PBS and then fixed with $70 \%$ ice-cold ethanol. Fixed samples were stored in $4{ }^{\circ} \mathrm{C}$ overnight. After, cells were washed with PBS and the cell number was adjusted to $1 \times 10^{6}$ cells per ml. Cells were incubated with $0.5 \mathrm{ml}$ of phosphate-citrate buffer $\left(0.2 \mathrm{M} \mathrm{Na}_{2} \mathrm{HPO}_{4}, 0.1 \mathrm{M}\right.$ citrate, $\mathrm{pH}$ 7.8), washed with PBS and stained with $0.5 \mathrm{ml}$ of Vindelov's solution ( $1.2 \mathrm{~g} / 1 \mathrm{TRIS}, 0.6 \mathrm{~g} / 1 \mathrm{NaCl}, 0.01 \mathrm{~g} / \mathrm{l}$ RNAse, and $0.05 \mathrm{~g} / 1$ propidium iodide) at $37{ }^{\circ} \mathrm{C}$ for $1 \mathrm{~h}$ in dark. Stained samples were analyzed on flow cytometer (Cell Lab Quanta SC MPL Flow Cytometer, Beckman Coulter, USA) equipped with $488 \mathrm{~nm}$ laser in FL2 channel.

\section{Western blot analysis}

Control and treated cells were trypsinized after $24 \mathrm{~h}$ incubation interval, washed with PBS and centrifugated 5 min at $1000 \mathrm{rpm}$ and $4{ }^{\circ} \mathrm{C}$. Pellets were resuspended in $5 \mathrm{ml}$ of ice-cold lysis buffer (137 mmol NaCl, 10\% glycerol, 1\% n-octyl- $\beta$-D-glucopyranoside, $50 \mathrm{mmol} \mathrm{NaF}, 20 \mathrm{mmol}$ Tris, $1 \mathrm{mmol}$ sodium orthovanadate, Complete TM Mini). Cell lysates were boiled for $5 \mathrm{~min}$ at $95^{\circ} \mathrm{C}$ in SDS sample buffer (Tris-HCl pH 6.81, 2-mercaptoethanol, 10\% glycerol, SDS, $0.1 \%$ bromphenol blue). Samples were loaded onto a $15 \%$ polyacrylamide gel. All lysates contained equal amount of protein, $40 \mu \mathrm{g}$, and it was determined by BCA assay. Electroforetically separated proteins were transfered to a PVDF membrane $(100 \mathrm{~V}, 1 \mathrm{~h})$ and then incubated at $25{ }^{\circ} \mathrm{C}$ for $1.5 \mathrm{~h}$ with a $5 \%$ non fat dry milk, $10 \mathrm{mmol}$ Tris- $\mathrm{HCl}(\mathrm{pH} 8.0)$, $150 \mathrm{mM} \mathrm{NaCl}$ and $0.1 \%$ Tween 20 (TBST - Tris-Buffered Saline Tween 20). Membranes were then incubated with primary antibodies (polyclonal rabbit anti-Cdc25A 
$1: 100$, polyclonal rabbit anti-cyclin B1 $1: 200$, monoclonal mouse anti-cyclin D1 1:100, monoclonal mouse antiPCNA $1: 1000$, rabbit anti-BAX $1: 200$, monoclonal rabbit anti-XIAP $1: 100$, monoclonal mouse anti-p53 $1: 100$, monoclonal mouse anti- $\beta$-actin $1: 10,000$ (all from Cell Signaling Technology, Inc., USA) and monoclonal mouse anti-p21 1: 200 (Santa Cruz Biotechnology, Santa Cruz, USA)) at $4{ }^{\circ} \mathrm{C}$ over night followed by five 6 min washes in TBST. Then membranes were incubated with secondary peroxidase-conjugated antibodies $\left(1: 1000,1 \mathrm{~h}, 25^{\circ} \mathrm{C}\right.$; Dako, Denmark), washed with TBST and the signal was developed by chemiluminescence detection kit (ECL, Boehringer Mannheim-Roche, Switzerland). $\beta$-actin was used as a loading control. Density of protein-specific signals was evaluated by Carestream molecular imaging software (Carestream Health, Inc., USA).

\section{Caspase 3 activity}

Control and treated cells were harvested by centrifugation $(600 \times \mathrm{g}, 5 \mathrm{~min})$ and lysed on ice for $20 \mathrm{~min}$ in a lysis buffer (50 mM HEPES, 5mM CHAPS, $5 \mathrm{mM}$ DTT). Cell lysates were centrifugated by $14,000 \times \mathrm{g}, 10 \mathrm{~min}$ and $4{ }^{\circ} \mathrm{C}$, the supernatants were collected and stored at $-80^{\circ} \mathrm{C}$. The caspase 3 activity was measured in 96-well microtitrate plates with the use of a kinetic fluorimetric assay based on the hydrolysis of the peptide substrate Ac-DEVD-AMC by caspase 3 . This results in the release of the fluorescent 7-amino-4-methylcoumarin (AMC) moiety. Ac-DEVD-CHO, a specific inhibitor of caspase 3, was used to confirm the specifity of the cleavage for caspase 3 . Fluorescence was measured by photometer at excitation $\lambda 360 \mathrm{~nm}$ and emmision $\lambda 465 \mathrm{~nm}$. The concentration of the AMC released was calculated from a standard curve constructed with known concentrations of AMC. Caspase 3 activity was expressed as nmol AMC/min/mg protein. Proteins were determined spectrophotometrically with the use of bicinchoninic acid and bovine serum albumin as a standard.

\section{Statistical analysis}

Statistical analysis was carried out using the Student's t-test. Results were considered statistically significant at $\mathrm{p}<0.05$.

\section{Results}

\section{Cell proliferation assays}

\section{MTT assay}

The effect of tested cytostatics on proliferation of A2780 cells was evaluated by MTT cell proliferation assay (Fig. 1, Tab. 2). The highest inhibition of proliferation showed cells treated with paclitaxel, gemcitabine and topotecan. The cell cultures were least sensitive to carboplatin and etoposide treatment. The middle inhibition concentration $\mathrm{c}_{4}$ for each cytostatic was chosen for further studies (morphological analysis, cell cycle and cell death analysis).

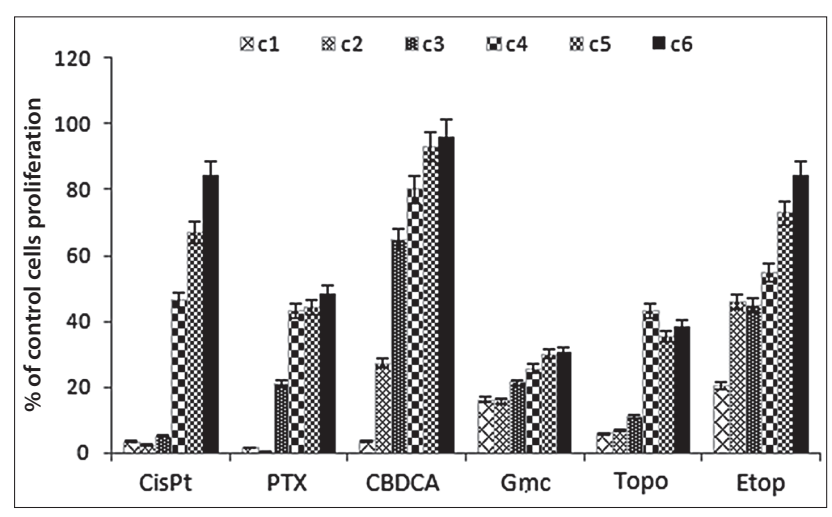

Fig. 1: Antiproliferative effect of selected cytostatics in the A2780 cell line detected by MTT assay. CisPt - cisplatin, PTX - paclitaxel, CBDCA - carboplatin, Gmc - gemcitabine, Topo - topotecan, Etop - etoposide. Results represent means of nine independent experiments

Tab. 2: EC50 values of selected cytostatics in the A2780 cell line obtained from MTT compared with EC50 values calculated by the xCELLigence RTCA software

\begin{tabular}{|l|c|c|}
\hline \multirow{2}{*}{ Cytostatics } & \multicolumn{2}{|c|}{ EC50 \pm SD } \\
\cline { 2 - 3 } & MTT & xCELLigence \\
\hline CisPt & $1.36 \mathrm{E}+00 \pm 7.55 \mathrm{E}-01$ & $5.59 \mathrm{E}-01 \pm 1.87 \mathrm{E}-02$ \\
\hline PTX & $7.81 \mathrm{E}-01 \pm 4.67 \mathrm{E}-01$ & $4.72 \mathrm{E}-03 \pm 5.65 \mathrm{E}-04$ \\
\hline CBDCA & $1.37 \mathrm{E}+01 \pm 5.16 \mathrm{E}+00$ & $3.83 \mathrm{E}+01 \pm 6.06 \mathrm{E}+00$ \\
\hline Gmc & NA & $1.54 \mathrm{E}-02 \pm 6.17 \mathrm{E}-03$ \\
\hline Topo & NA & $1.47 \mathrm{E}-02 \pm 2.60 \mathrm{E}-03$ \\
\hline Etop & $1.88 \mathrm{E}+00 \pm 4.18 \mathrm{E}-01$ & $2.92 \mathrm{E}-01 \pm 3.25 \mathrm{E}-02$ \\
\hline
\end{tabular}

CisPt - cisplatin, PTX - paclitaxel, CBDCA - carboplatin, Gmc - gemcitabine, Topo - topotecan, Etop - etoposide. EC50 values from MTT are means of nine independent experiments and EC50 values from xCELLigence are means of three independent experiments. SD - standard deviation, NA - not applicable: Our model cell line A2780 is very sensitive to gemcitabine and topotecan treatment. EC50 values from MTT assay are not countable for these cytostatics. These values are smaller than minimal tested concentrations of cytostatics.

\section{$x$ CELLigence}

Antiproliferative effect of tested cytostatics in A2780 cells was further evaluated by the xCELLigence system and EC50 values were calculated by its RTCA software for 
individual cytostatics after $72 \mathrm{~h}$ of treatment (Tab. 2). The highest EC50 values were reached for carboplatin, high EC50 values were acquired also after cisplatin and etoposide treatment. The lowest EC50 values were detected after paclitaxel treatment.

\section{Morphological studies}

To evaluate morphological changes of cells treated with cytostatics, a time-lapse study of control and treated cells were observed by Olympus IX70 at magnification 400× in time intervals $0 \mathrm{~h}, 24 \mathrm{~h}, 48 \mathrm{~h}$, and $72 \mathrm{~h}$. While control samples proliferated and reached confluence by $72 \mathrm{~h}$ of cultivation, cells treated with cytostatics gradually lost their adherence to the surface and displayed intensive blebbing typical for apoptotic cell death. The earliest changes in morphology were detected in case of paclitaxel, followed by gemcitabine, topotecan and etoposide (Fig. 2).

\section{Cell cycle analysis}

\section{Cell cycle distribution}

Tested cytostatics in the middle inhibition concentration $\left(\mathrm{c}_{4}\right)$ changed the cell cycle distribution of the A2780 cells (Fig. 3). Cisplatin, carboplatin and gemcitabine increased the proportion of cells in $\mathrm{G} 1 / \mathrm{S}$ phases of the cell cycle. Topotecan and etoposide induced accumulation of cells in $\mathrm{S}$ phase, this effect was more prolonged in case of topotecan. Paclitaxel blocked the cell cycle in G2 phase up to 6 hours after treatment, followed by increase in $\mathrm{S}$ phase at $12 \mathrm{~h}$ and and G1 phase at $24 \mathrm{~h}$.

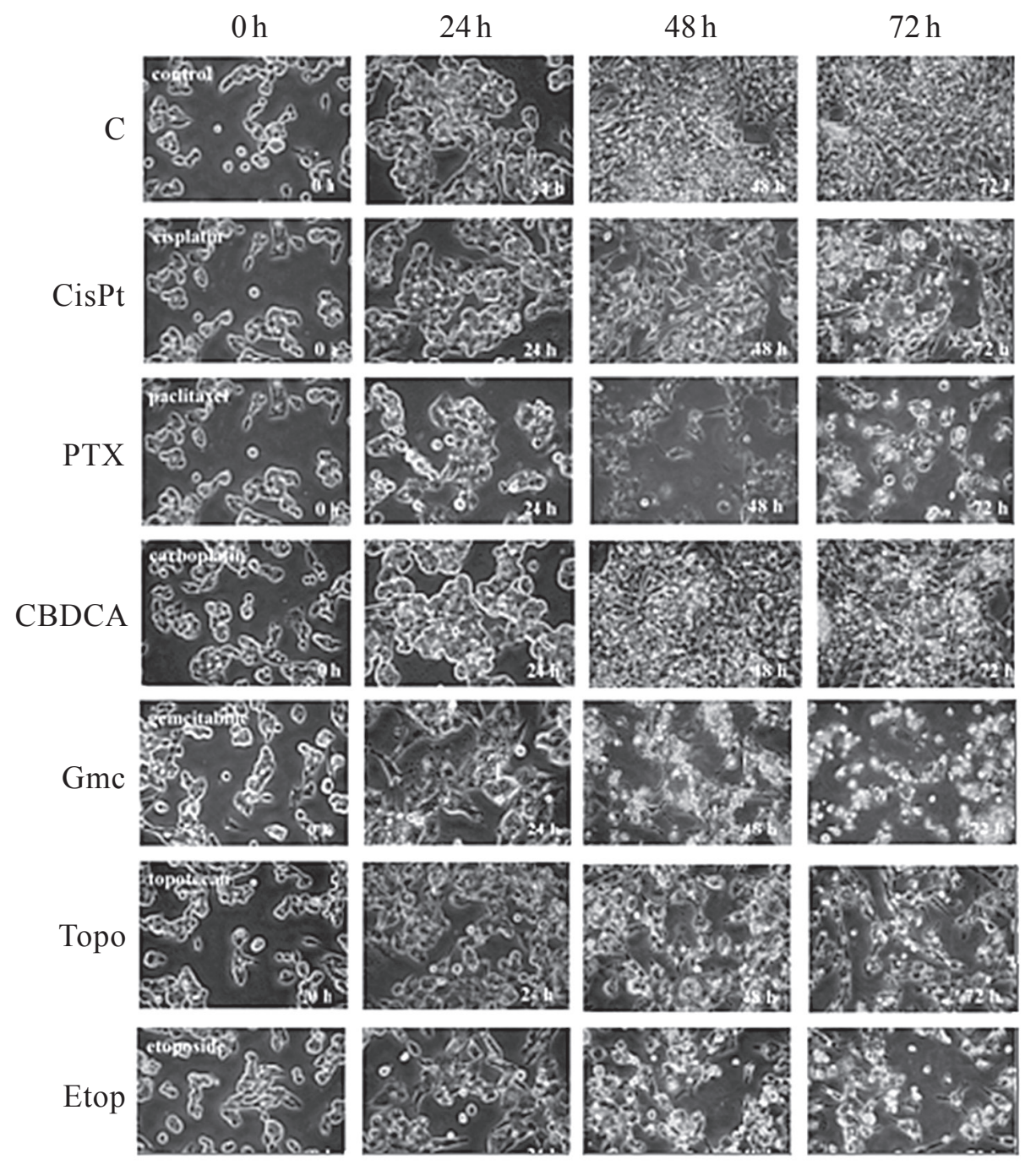

Fig. 2: Morphological changes in A2780 cells treated with the middle inhibition concentration of selected cytostatics ( $\mathrm{c}_{4}$ ) for $72 \mathrm{~h}$. Magnification 400×. C - control, CisPt - cisplatin, PTX - paclitaxel, CBDCA - carboplatin, Gmc - gemcitabine, Topo - topotecan, Etop - etoposide. Experiments were three times repeated 


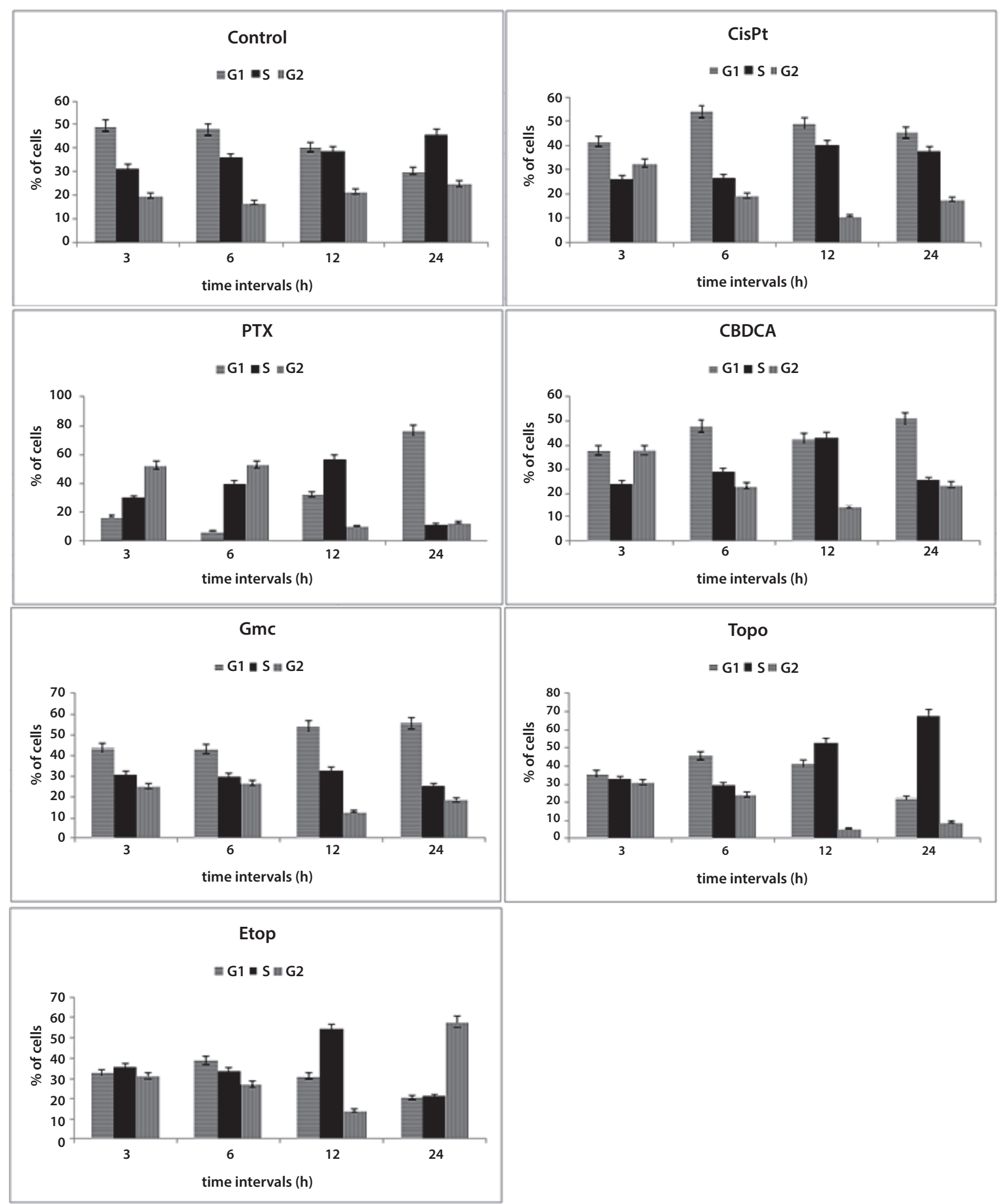

Fig. 3: Changes in cell cycle distribution of A2780 cells treated with the middle inhibition concentration $\left(\mathrm{c}_{4}\right)$ of tested cytostatics during $24 \mathrm{~h}$. Experiments were three times repeated 


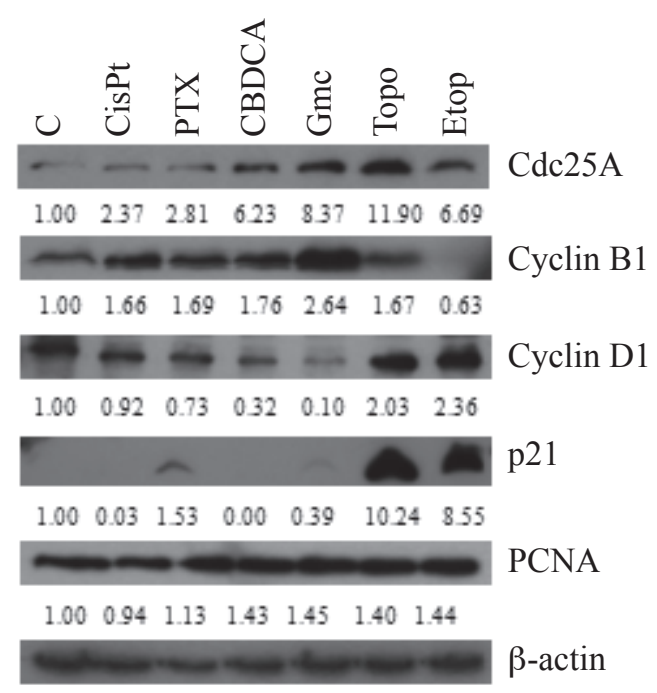

Fig. 4a: Changes in protein expression (cell cycle markers) of A2780 cells treated with the middle inhibition concentration $\left(\mathrm{c}_{4}\right)$ analyzed by western blot analysis. $24 \mathrm{~h}$ incubation interval, $15 \%$ PAAG gel, $40 \mu \mathrm{g} / \mathrm{ml}$ protein concentration. Dilution of antibodies Cdc25A (1:100), cyclin B1 $(1: 200)$, cyclin D1 $(1: 100)$, p21 $(1: 200)$, PCNA $(1: 1000)$ and $\beta$-actin $(1: 10,000)$. C - control, CisPt - cisplatin, PTX - paclitaxel, CBDCA - carboplatin, Gmc - gemcitabine, Topo - topotecan, Etop - etoposide. Data were analyzed by Carestream molecular imaging software. Experiments were two times repeated

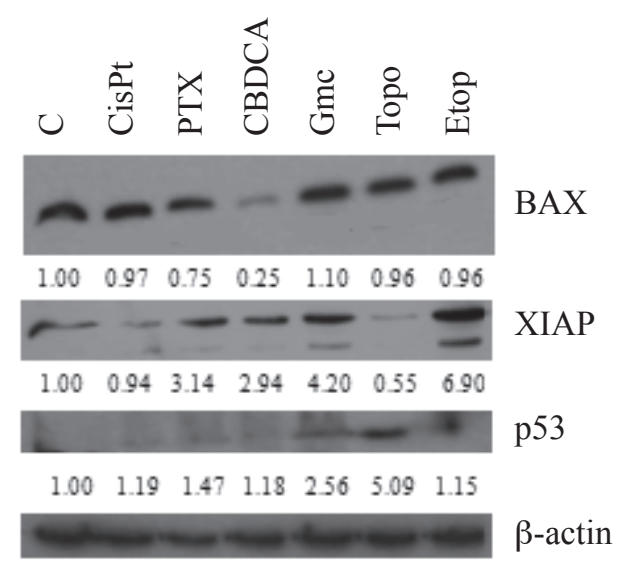

Fig. 4b: Changes in protein expression (apoptotic markers) of A2780 cells treated with the middle inhibition concentration $\left(\mathrm{c}_{4}\right)$ analyzed by western blot analysis. $24 \mathrm{~h}$ incubation interval, $15 \%$ PAAG gel, $40 \mu \mathrm{g} / \mathrm{ml}$ protein concentration. Dilution of antibodies BAX $(1: 200)$, XIAP $(1: 100)$, p53 (1:100) and $\beta$-actin $(1: 10,000)$. C - control, CisPt - cisplatin, PTX - paclitaxel, CBDCA - carboplatin, $\mathrm{Gmc}$ - gemcitabine, Topo - topotecan, Etop - etoposide. Data were analyzed by Carestream molecular imaging software. Experiments were two times repeated

\section{Cell cycle protein analysis}

Cytostatics in selected concentration $\left(\mathrm{c}_{4}\right)$ influenced the protein expression of cell cycle markers after $24 \mathrm{~h}$ of treatment as shown in Fig. 4a. Cdc25A protein phosphatase was up-regulated in all treated samples, the highest values were detected in case of topotecan and gemcitabine, followed by etoposide and carboplatin. Cyclin B1 expression was up-regulated after treatment with all tested cytostatics with the exception of etoposide, the most prominent increase was associated with gemcitabine followed by carboplatin, paclitaxel, topotecan and cisplatin. Cyclin D1 expression was increased after topotecan and etoposide treatment, but decreased after paclitaxel, carboplatin and mainly gemcitabine treatment. p21 was up-regulated after the treatment with topotecan, etoposide, paclitaxel and gemcitabine. PCNA expression was increased in cells treated with gemcitabine, etoposide, carboplatin, topotecan and moderately with paclitaxel.

\section{Cell death analysis}

\section{Western blot}

Cytostatics tested in middle concentration $\left(\mathrm{c}_{4}\right)$ influenced the expression of apoptotic markers as shown in Fig. 4b. Bax expression was decreased in cases of carboplatin and paclitaxel. XIAP as an inhibitor of apoptosis proteins, especially caspases 3 and 7, was up-regulated after gemcitabine, etoposide, paclitaxel and carboplatin treatment, but down-regulated in case of topotecan treatment. The expression of p53 was up-regulated after topotecan treatment.

\section{Caspase 3 activity}

Selected cytostatics tested in middle inhibition concentration $\left(\mathrm{c}_{4}\right)$ affected the activity of caspase 3 during $72 \mathrm{~h}$ of incubation. The lowest activity of caspase 3 was detected after carboplatin treatment. On the contrary, the quickest and the highest activity of caspase 3 was detected after topotecan treatment (Fig. 5). In case of the other tested cytostatics the highest activity of caspase 3 was detected after $24 \mathrm{~h}$ from the treatment.

\section{Discussion}

This study evaluates the anti-proliferative and cytotoxic effect of a panel of selected cytostatics in a model ovarian carcinoma cell line A2780. Of these cytostatisc, carboplatin, cisplatin and paclitaxel are use in first-line ovarian cancer treatment, while gemcitabine, topotecan and etoposide are use in alternative regimen or in monotherapy of second- and higher lines of ovarian cancer treatment (24). The selected cytostatics have different mechanisms of action. The alkylating agents platinum coordination complexes cisplatin and carboplatin form inter- and intrastrand DNA 


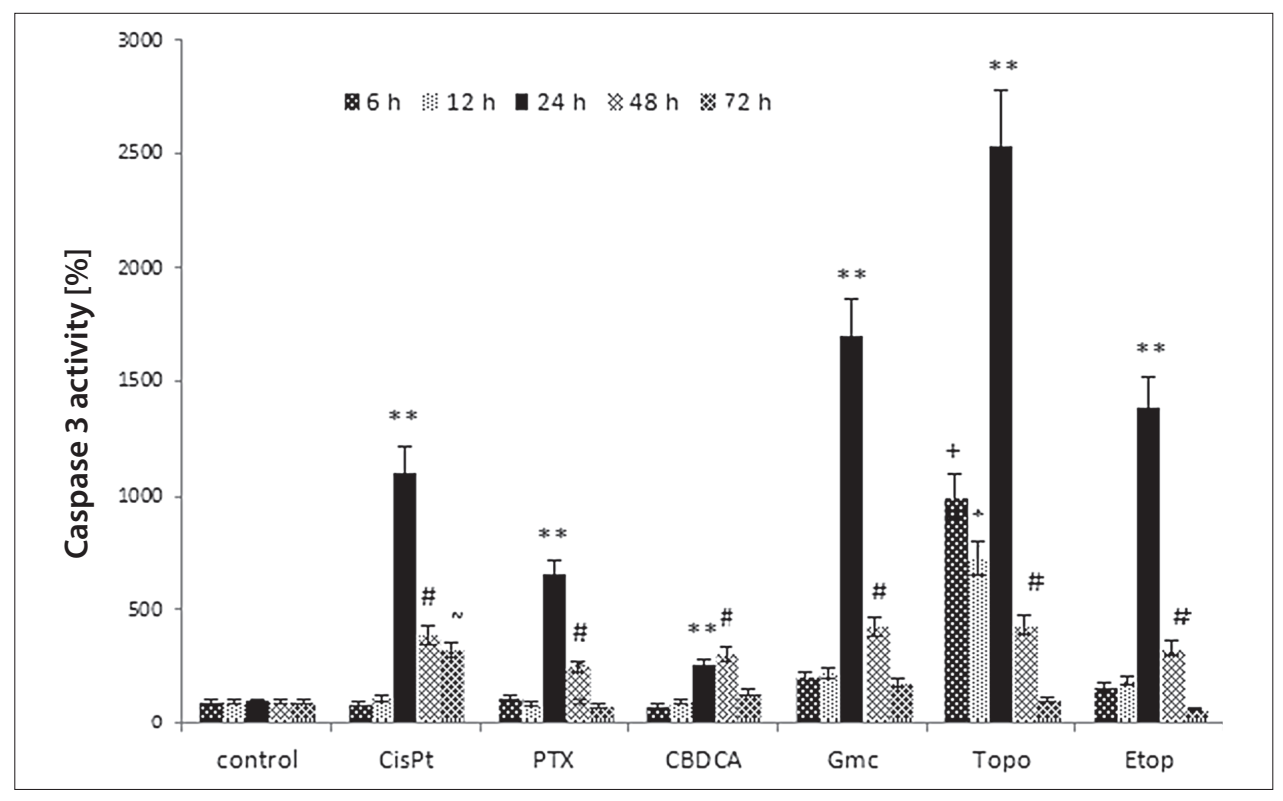

Fig. 5: Changes in caspase 3 activity in A2780 cell line treated with the middle inhibition concentration $\left(c_{4}\right)$ of tested cytostatics during $72 \mathrm{~h}$. CisPt - cisplatin, PTX - paclitaxel, CBDCA - carboplatin, Gmc - gemcitabine, Topo - topotecan, Etop - etoposide. + significantly higher against control in $6 \mathrm{~h}$ time interval, * significantly higher against control in $12 \mathrm{~h}$ time interval, ** significantly higher against control in $24 \mathrm{~h}$ time interval, \# significantly higher against control in $48 \mathrm{~h}$ time interval, significantly higher against control in $72 \mathrm{~h}$ time interval. Student's t-test, $\mathrm{p}<0.05$ was considered as statistically significant. Results are means of two independent experiments

crosslinks (9). The taxan derivative paclitaxel blocks the cell division by stabilization of microtubuli. Chromosomes are thus unable to achieve a metaphase spindle configuration. This blocks progression of mitosis and prolonged activation of the mitotic checkpoint triggers apoptosis or reversion to the G-phase of the cell cycle without cell division $(3,6)$. Gemcitabine, the pyrimidine analogue, inhibits processes required for DNA synthesis (31). The topoisomerase I inhibitor topotecan intercalates between DNA bases. This intercalation disrupts the DNA duplication machinery when it reaches a site where topotecan is intercalated. This disruption prevents DNA replication, and ultimately leads to cell death (35). Finally the topoisomerase II inhibitor etoposide forms a ternary complex with DNA and the topoisomerase II enzyme, preventing re-ligation of the DNA strands. This causes errors in DNA synthesis and promotes apoptosis of the cell (19).

To describe the anti-proliferative effect of the selected cytostatics we employed the MTT assay that detects the activity of mitochondrial succinate dehydrogenase (13) and combined it with the dynamic monitoring of cell proliferation with the xCELLigence system. This new method has proven to be a valuable tool for label-free real time monitoring of cellular proliferation and adhesion that has some advantages over the standard end-point assays and is now widely used to monitor the compound-mediated cytotoxicity (32). This study showed, that EC50 values obtained with $\mathrm{xCELLigence} \mathrm{were} \mathrm{lower} \mathrm{compared} \mathrm{to} \mathrm{those} \mathrm{obtained}$ with the MTT assay, so xCELLigence detected the anti-proliferative effect of the tested drugs with higher sensitivity.

The concentration range of tested cytostatics was chosen according to the schedule employed in the previous testing of the clinical samples (5). The highest anti-proliferative effect was observed with paclitaxel, gemcitabine and topotecan. For further experiments we selected concentrations presented as $\mathrm{c}_{4}$, nearest to the EC50 values for selected cytostatics obtained in testing of clinical samples.

Selected cytostatics in tested concentration changed the cell cycle distribution during $24 \mathrm{~h}$ treatment of A2780 cells. Cisplatin, carboplatin and gemcitabine increased the proportion of cells in G1/S phases of the cell cycle. All these cytostatics finally inhibit DNA synthesis and this correlates with the cell cycle distribution. Topotecan and etoposide induced accumulation of cells in S phase, this effect was more prolonged in case of topotecan. Topotecan inhibits topoisomerase I and etoposide inhibits topoisomerase II. Both enzymes are needed during DNA replication and their inhibition leads to the inhibition of DNA synthesis. Treatment with $0.78 \mu \mathrm{g} / \mathrm{ml}\left(\mathrm{c}_{4}\right)$ paclitaxel blocked the cell cycle in $\mathrm{G} 2$ phase up to 6 hours after treatment, followed by increase in S phase at $12 \mathrm{~h}$ and and G1 phase at $24 \mathrm{~h}$. This finding correlates with the mechanism of action of paclitaxel, which stops cell cycle in G2/M phase. This behaviour most probably reflects the dynamics of the cell proliferation and cell death during the $24 \mathrm{~h}$ interval and is caused by the depletion of cells in G2 phase due to apoptosis. 
Protein expression detected by western blot was changed after the cytostatics treatment. Cdc25A protein phosphatase plays a critical role in activating cyclin-dependent kinases (CDKs) and induces G1/S phase cell cycle transit. Normal cell cycle progression leads to increased cdc25A expression (37). Its expression was most prominently up-regulated in topotecan-treated cells, higher expression in comparison to control samples was also detected after carboplatin, gemcitabine and etoposide treatment. After $24 \mathrm{~h}$ from the treatment cells were not inhibited in $\mathrm{G} 1 / \mathrm{S}$ phase cell cycle progression. Upregulation of mitotic cyclin B1, marking the block in the transition into the mitotic phase, was detected in all treated samples with the exception of etoposide. Cell cycle distribution after etoposide treatment showed about $60 \%$ of cells accumulated in G2 phase. Cyclin D1 regulates cyclin-dependent kinases and transition to $\mathrm{G} 1 / \mathrm{S}$ phase of cell cycle (22). Its expression was decreased in gemcitabine-treated cells, which correlates with the increase in G1 phase observed during cell cycle distribution analysis. Protein p21 is an inhibitor of cyclin-dependent kinases that inhibits the progression of cells through the cell cycle. Its expression is up-regulated by $\mathrm{p} 53$ in response to DNA damage $(12,15)$. Increased expression of p21 in A2780 cells was detected after topotecan and etoposide treatment in the $24 \mathrm{~h}$ time interval. In this time, the p53 expression was significantly increased only in topotecan-treated cells. The proliferating cell nuclear antigen PCNA is a member of the DNA sliding clamp family of proteins that assist in DNA replication (25). It is a well-accepted marker of cell proliferation, but it is also required for the DNA repair $(33,16)$. In case of A2780 cells, PCNA expression was increased after carboplatin, gemcitabin, topotecan and etoposide treatment. X-linked inhibitor of apoptosis protein XIAP binds to and inhibits caspases 3, 7, and 9 (14). It blocks the apoptosis as a result of the inhibition of effector caspases. Its highest expression was detected in etoposide-treated cells and then after gemcitabine, carboplatin and paclitaxel treatment too, which correlates with relatively lower caspase 3 activity observed after the treatment with these cytostatics in comparison to the others. XIAP expression was decreased in topotecan-treated cells in comparison to control samples, and topotecan-treated cells also showed the highest expression of $\mathrm{p} 53$ protein and highest activity of caspase 3 .

Bcl-2 and Bax are transcription targets for tumor supressor protein $\mathrm{p} 53$. The expression of proapoptotic protein Bax can be induced by cytostatics (1). Protein Bax promote the activity of effector caspase 3 and thereby apoptosis. Bax as a member of BCL2 protein family is an activator of apoptosis. Expression of Bax was significantly decreased in carboplatin-treated A2780 cells. This is in correlation with the activity of caspase 3 , which was lowest after carboplatin treatment.

Activation of caspases is associated with induction of apoptosis. Caspase 3, one of the effector caspases, induces proteolytic activation of many cell proteins, apoptosis-associated chromatin migration, DNA fragmentation and nuclear collapse (34). Quantifiable markers of apoptosis such as caspase 3 activation have the potential to predict the clinical response to chemotherapy (17). We detected significantly elevated levels of activated caspase 3 in A2780 cells after $24 \mathrm{~h}$ treatment with tested cytostatics, with the highest activity observed in case of topotecan, followed by gemcitabine, etoposide and cisplatin. Paclitaxel, which showed the highest antiproliferative effect in MTT and xCELLigence assays as well as in the morpohological studies, did not prove that effective in elevating caspase 3 activity in treated cells. The lowest caspase 3 activity detected was associated with carboplatin treatment, which is in correlation with the results found in literature $(27,28)$.

Several studies compared the reactivity of platinum derivatives and paclitaxel (first line cytostatics treatment) in both sensitive and resistant model cell lines $(2,18,11)$. A2780 cells as a cisplatin-sensitive cell line has been used as a model in in vitro ovarian cancer studies, that tested anti-proliferative effects of platinum derivatives (21), paclitaxel (38) and the combination of these cytostatics (23). In our study we tested wider panel of cytostatics that covers the first and second line drugs employed in clinics. Results of our in vitro chemosensitivity testing in A2780 model cell line showed for the first time that the most effective antiproliferative effect was associated with topotecan treatment. Topotecan in comparison to other selected cytostatic drugs also induced the highest expression of key molecule p53, low expression of XIAP or the highest detected caspase 3 activity. Topotecan, topoisomerase I inhibitor, has been used for the treatment of recurrent metastatic ovarian cancer and also many other types of cancer. Topotecan has demonstrated antitumour activity in platinum-sensitive, platinum-resistant, and paclitaxel-resistant tumours (10, $26,36)$. Effectivity of topotecan in our model cell line correlates with results of our previous study using cells isolated from clinical samples (5), which may support the idea to use this cytostatic in the first-line chemotherapy treatment of ovarian cancer patients.

\section{Conclusions}

In this study we tested a wide panel of cytostatics in a model ovarian cancer cell line A2780. Selected cytostatics cover the first- and second-line drugs employed in treatment of ovarian cancer and included cisplatin, paclitaxel, carboplatin, gemcitabine, topotecan and etoposide. The results showed time- and dose-dependent toxicity of model A2780 cell line to selected cytostatics, the most effective antiproliferative effect was associated with topotecan treatment, which correlates with results of our previous study using cells isolated from clinical samples.

\section{Acknowledgements}

This work was supported by project PRVOUK P37/01. 


\section{References}

1. Basu A, Haldar S. The relationship between bcl-2, bax and p53: Consequence for cell cycle progression and cell death. Mol Hum Reprod 1998; 4: 1099-1109.

2. Behrens BC, Grotzinger KR, Hamilton TC et al. Cytotoxicity of 3 cisplatin (CP) analogues in a drug-sensitive and a new $\mathrm{CP}$ resistant human ovarian cancer (OC) cell line. Proc. Am. Assoc. Cancer Res. 1985; 26: 262

3. Bharadwaj R, Yu H. The spindle checkpoint, aneuploidy, and cancer. Oncogene 2004; 23(11): 2016-27

4. Bolis G, Scarfone G, Polverino G et al. Paclitaxel 175 or $225 \mathrm{mg}$ per meter squared with carboplatin in advanced ovarian cancer: a randomized trial. J Clin Oncol 2004; 22: 686-690.

5. Brigulová K, Červinka M, Tošner J et al. Chemoresistance testing of human ovarian cancer cells and its in vitro model. Toxicol in vitro 2010;24: 2108-15.

6. Brito DA, Yang Z, Rieder CL. Microtubules do not promote mitotic slippage when the spindle assembly checkpoint cannot be satisfied. The Journal of Cel Biology 2008; 182(4): 623-9.

7. Chobanian N, Dietrich CS. Ovarian cancer. Surg. Clin. North Am. 2008; 88(2): 285-99.

8. Cibula D, Petruželka L et al. Oncogynecology. Prague, Grada Publishing 2009: 614

9. Conklin KA. Cancer chemotherapy and antioxidants. J. Nutr. 2004; vol. 134 no. 11 .

10. Creemers GJ, Bolis G, Gore M et al. Topotecan, an active drug in the second-line treatment of epithelial ovarian cancer: results of a large European phase II study. J Clin Oncol 1996; 14: 3056-61.

11. Debernardis D, Siré EG, Feudis P et al. p53 status does not affect sensitivity of human ovarian cancer cell lines to paclitaxel. Cancer Res 1997; 57: 870.

12. Deng C, Zhang P, Harper JW et al. Mice lacking p21CIP1/WAF1 undergo normal development, but are defective in G1 checkpoint control. Cell 1995; 82: 675-684.

13. Denizot F, Lang R. Rapid colorimetric assay for cell growth and survival. Modifications to the tetrazolium dye procedure giving improved sensitivity and reliability. J Immunol Methods 1986; 89: 271-7.

14. Deveraux QL, Reed JC. IAP family proteins - suppressors of apoptosis. Genes Dev. 1999; 13(3): 239-52.

15. Dulic V, Kaufman WK, Wilson SJ et al. p53-dependent inhibition of cyclin-dependent kinase activities in human fibroblasts during radiation-induced G1 arrest. Cell 1994; 76: 1013-1023.

16. Essers J, Theil AF, Baldeyron C et al. Nuclear dynamics of PCNA in DNA replication and repair. Mol. Cell. Biol. 2005; 25(21): 9350-9359.

17. Flick MB, O'Malley D, Rutherford T et al. Apoptosis-Based Evaluation of Chemosensitivity in Ovarian Cancer Patients. Reproductive Sciences. 2004; 11(4) 252-259.

18. Godwin AK, Meister A, O’Dwyer PJ et al. High resistance to cisplatin in human ovarian cancer cell lines is associated with marked increase of glutathione synthesis. Proc. Natl. Acad. Sci. USA 1992; 89:3070-74.

19. Gordaliza M, García PA, Corral JM et al. Podophyllotoxin: distribution, sources, applications and new cytotoxic derivatives. Toxicon 2004; 44(4): 441-59.

20. Gore ME, Fryatt I, Wiltshaw E et al. Treatment of relapsed carcinoma of the ovary with cisplatin or carboplatin following initial treatment with these compounds. Gynecol Oncol 1990; 36: 207-11.

21. Henkels KM, Turchi JJ. Induction of apoptosis in cisplatin-sensitive and-resistant human ovarian cancer cell lines. Cancer Research 1997; 57: 4488-92.

22. Johnson DG., Walker CL. Cyclins and cell cycle checkpoints. Annu. Rev. Pharmacol. Toxicol. 1999; 39: 295-312.

23. Jones NA, Turner J, McIlwrath AJ et al. Cisplatin- and Paclitaxel-Induced Apoptosis of Ovarian Carcinoma Cells and the Relationship between Bax and Bak Up-Regulation and the Functional Status of p53. Molecular Pharmacology 1998; (53)5: 819-26.

24. Kalábová R. Docetaxel - the use in the treatment of advanced and relapsing ovarian cancer. Gynekolog 2005; 1: 6-8.

25. Kelman Z, O'Donnell M. Structural and functional similaritites of prokaryotic and eukaryotic DNA polymerase sliding clamps. Nucleic Acids Res. 1995; 23 3613-20.

26. Kudelka AP, Tresukosol D, Edwards CL et al. Phase II study of intravenous topotecan as a 5-day infusion for refractory epithelial ovarian carcinoma. J Clin Oncol 1996; 14: 1552-57.

27. Ludwig T, Oberleithner H. Platinum complex toxicity in cultured renal epithelia. Cell Physiol Biochem 2004; 14: 431-40.

28. Ludwig T, Riethmüller Ch, Gekle M et al. Nephrotoxicity of platinum complexes is related to basolateral organic cation transport. Kidney International 2004; 66 : 196-202.

29. Markman M, Rothman R, Hakes T et al. Second-line platinum therapy in patients with ovarian cancer previously treated with cisplatin. J Clin Oncol 1991; 9: 389-93.

30. Ozols RF et al. Contemporary issues in the management of ovarian cancer. Sem Oncol 2000; 27(suppl 7): 1-2.

31. Plunkett W, Huang P, Xu YZ et al. Gemcitabine: metabolism, mechanisms of action, and self-potentiation. Semin Oncol. 1995; 22(4 Suppl 11): 3-10.

32. Roche Diagnostics GmbH. xCELLigence System, Application Note No. 1. Realtime and Dynamic Monitoring of Cell Proliferation and Viability for Adherent Cells. 2008. (Accessed at http://www.um.es/sai/documentos/historico/2009 /sct_Excelligence_2009//excellig1.pdf.)

33. Shivji KK, Kenny MK, Wood RD. Proliferating cell nuclear antigen is required for DNA excision repair. Cell 1992; 69(2): 367-74

34. Slee EA, Adrain C, Martin SJ. Executioner caspase 3, -6, and -7 perform distinct, non-redundant roles during the demolition phase of apoptosis. J Biol Chem 2001; 276: $7320-26$

35. Staker BL, Hjerrild K, Feese MD et al. The mechanism of topoisomerase I poisoning by a camptothecin analog. PNAS 2002; 99(24): 15387-92.

36. Swisher EM, Mutch DG, Rader JS et al. Topotecan in platinum- and paclitaxel-resistant ovarian cancer. Gynecol Oncol 1997; 66: 480-86.

37. Vigo E, Müller H, Prosperini E et al. CDC25A phosphatase is a target of E2F and is required for efficient E2F-induced S phase. Mol Cell Biol 1999; 19(9): 6379-95.

38. Vikhanskayaa F, Vignatia S, Beccagliaa P et al. Inactivation of $\mathrm{p} 53$ in a Human Ovarian Cancer Cell Line Increases the Sensitivity to Paclitaxel by Inducing G2/M Arrest and Apoptosis. Experimental Cell Research 1998; 241(1): 96-101.

Received: 14/06/2012

Accepted in revised form: 22/08/2012

\section{Corresponding author:}

Mgr. Kateřina Caltová, Charles University in Prague, Faculty of Medicine in Hrádec Králové, Department of Medical Biology and Genetics, Šimkova 870, 50038 Hradec Králové, Czech Republic; e-mail: brigulovak@lfhk.cuni.cz 